J. Amer. Soc. Hort. Sci. 116(3):383-389. 1991.

\title{
Peach Fruit Quality Is Affected by Shade during Final Swell of Fruit Growth
}

\author{
Richard P. Marini', Donald Sowers ${ }^{2}$, and Michele Choma Marini ${ }^{3}$ \\ Department of Horticulture, Virginia Polytechnic Institute \& State University, Blacksburg, \\ VA 24061 \\ Additional index words. Prunus persica, photosynthetic photon flux density, light levels, soluble solids content, \\ anthocyanin
}

\begin{abstract}
Girdled or nongirdled 'Biscoe' peach (Prunus persica [L.] Batsch) secondary scaffold branches were covered with shade fabric to provide a range of photosynthetic photon flux densities (PPFD) from 44 to 20 days before harvest (DBH), from 20 to $0 \mathrm{DBH}$ or 44 to $0 \mathrm{DBH}$. Fruit quality was affected differently by the various periods of shade during the final swell of fruit development. Shading 40 to 20 DBH did not affect fruit weight or quality, whereas shading 44 to $0 \mathrm{DBH}$ had the greatest effect on fruit weight and quality. Fruit quality was generally similar on branches exposed to $100 \%$ and $45 \%$ incident PPFD (IPPFD). Fruit on" girdled branches generally responded to shade more than fruit on nongirdled branches. Fruit weight was positively related to percent IPPFD for girdfed but not nongirdled branches shaded 20 to 0 DBH and 44 to DBH. On nongirdled branches, fruit exposed to 45\% IPPFD for 44 to 0 DBH had $14 \%$ less red color and $21 \%$ lower soluble solids content (SSC) than nonshaded fruit. Harvest was delayed >10 days and preharvest fruit drop was increased by shading to $<23 \%$ IPPFD. Shading branches for 20 to 0 or 44 to 0 DBH altered the relationship between flesh firmness and ground color: Firmness declined as ground color changed from green to yellow for fruit shaded 44 to $20 \mathrm{DBH}$, but firmness declined with little change in ground color for fruit shaded 20 to 0 or 44 to $0 \mathrm{DBH}$. Girdling results indicated that fruit weight and SSC partially depended on photosynthate from nonshaded portions of the canopy, whereas fruit redness, days from bloom to harvest, and ground color depended on PPFD in the vicinity of the fruit.
\end{abstract}

Fruit quality is positively associated with PPFD within the canopies of several fruit species. Seeley et al. (1980) showed that apple size, degree of redness, and MC increased linearly with PPFD for fruit on shaded 'Delicious' limbs, and Morgan et al. (1984) found similar relationships for 'Gala' fruit developing at various canopy positions. Patten and Proebsting (1986) found that redness and SSC of 'Bing' cherries increased logarithmically with PPFD at various canopy locations. Southwick et al. (1990) reported that fresh weight, dry weight, and sugar content of prunes developing at various canopy locations were linearly related to PPFD. Although shade experiments have not been performed with peach, Rom et al. (1984) found that fruit redness was linearly correlated with percent full sun. Red pigmentation, flesh firmness, and SSC of peach fruit are influenced by canopy location, possibly due to differences in PPFD (Marini and Trout, 1984). Fruit from tree tops, where PPFD is greatest, are redder and have a higher SSC than fruit harvested with similar ground color from the tree interiors (Marini, 1985).

In open center peach trees, percent IPPFD is greatest at the tree periphery, lowest midway between the periphery and trunk, and intermediate at the tree center (Marini and Marini, 1983). Therefore, some regions of the canopy normally receive high PPFD, whereas other regions receive $\approx 10 \%$ IPPFD. Fruits near nonshaded leaves are most likely to develop optimum quality. However, the results of apple fruit thinning studies indicate that, although photosynthates are mobile within trees, fruit or other sinks adjacent to the sources are at a competitive advantage (Jackson, 1980). Girdling experiments indicate that sweet cherry spur leaves alone are not capable of supporting fruit growth and

Received for publication 12 Apr. 1989. The cost of publishing this paper was defrayed in part by the payment of page charges. Under postal-regulations, this paper therefore must be hereby marked advertisement solely to indicate this fact.

${ }^{1}$ Associate Professor.

${ }^{2}$ Laboratory Technician.

${ }^{3}$ Research Technician. that fruit depend on photosynthate translocated from other parts of the tree (Roper et al., 1987).

We found no reports quantifying the influence of light on various aspects of peach fruit quality. To optimize peach production through modification of tree shape and orchard design, the relationship between fruit quality and PPFD should be known. The objectives of this study were to quantify the relationship between various aspects of peach fruit quality and PPFD during the first and second halves of final fruit swell, and to determine the importance of photosynthate translocated to fruit developing in low PPFD.

\section{Materials and Methods}

Thirty-six 4-year-old 'Biscoe' peach trees were used for limb shading treatments in 1988. Trees spaced $5.2 \times 7.3 \mathrm{~m}$ were pruned to an open center and were $2.0 \mathrm{~m}$ tall and $2.5 \mathrm{~m}$ wide. Shade was produced with dome-shaped structures supported by PVC pipe and covered with black polypropylene shade fabric (E.C. Geiger, Harleysville, Pa.) to produce light levels of $45 \%$, 23\%, and 9\% IPPFD, as measured with a Lambda LI-1095 quantum sensor fitted to a Lambda LI-185A light meter (LICOR, Lincoln, Neb.). The structures had a maximum height of $2 \mathrm{~m}$ and a diameter of $2.8 \mathrm{~m}$. Shade fabric was placed over one primary scaffold limb that branched to form two secondary branches per tree. All limbs were on the south side of the tree and similar limbs on nonshaded trees served as controls. Sourcesink relations were altered by girdling one of the secondary scaffold branches per treatment scaffold limb on 11 July (97 DAFB, $44 \mathrm{DBH}$ ) by removing a 5-mm-wide strip of bark from around the base of the branch.

The three periods of limb shading were 11 July to 3 Aug. (97 to $120 \mathrm{DAFB}, 44$ to $20 \mathrm{DBH}), 3 \mathrm{Aug}$. to 9 Sept. (120 to

Abbreviations: DAFB, days after full bloom; DBH, days before harvest; IPPFD, incident photosynthetic photon flux density; PPFD, photosynthetic photon flux density. 
157 DAFB, 20 to $0 \mathrm{DBH}$ ), and 11 July to 9 Sept. (97 to 157 DAFB, 44 to $0 \mathrm{DBH})$. PPFD measured at 10 -sec intervals at a weather station $5.5 \mathrm{~km}$ from the orchard was integrated over each 24-h period. Total available PPF was $949 \mathrm{~mol} \cdot \mathrm{m}^{-2}$ for 11 July to $3 \mathrm{Aug}$. and $1385 \mathrm{~mol} \cdot \mathrm{m}^{-2}$ for $3 \mathrm{Aug}$. to 9 Sept. Average PPFD during daylight hours was 764 . and $729 \mu \mathrm{mol} \cdot \mathrm{s}^{-1} \cdot \mathrm{m}^{-2}-\mathrm{R}^{2}$ for 11 July to $3 \mathrm{Aug}$. and 3 Aug. to 9 Sept., respectively.. The factorial arrangement of two girdling treatments, four shade levels, and three shade periods resulted in 24 treatment combinations. There were three single-tree replicates per shade level per shade period in a completely randomized design.

On 7 June (63 DAFB) each tree was hand-thinned to a spacing of $\approx 15 \mathrm{~cm}$ between fruit. Each secondary scaffold branch used for shade treatments was thinned to a crop density (CD) of 6.1 \pm 0.6 fruit $/ \mathrm{cm}^{2}$ branch cross sectional area (BCSA).

Fruit were harvested, counted, and weighed on six harvest dates from 23 Aug. to 9 Sept. The harvest data were used to calculate the $\mathrm{H}_{50}$ (date at which $50 \%$ of the fruit were harvested) with the Spearman-Karber method (Bittenbender and Howell, 1974). We attempted to harvest only fruit with yellowish-green ground color, but heavy shade induced fruit abscission before desired ground color development. On 9 Sept., following 60\% to $80 \%$ fruit drop on heavily shaded trees, all remaining fruit were harvested regardless of ground color. Twenty fruit per branch, selected for uniformity of size on the last harvest date for each tree, were visually rated for percentage of the fruit surface that was red. The intensity of red pigmentation was rated on a scale of 1 to 4 , where $1=$ light and $4_{1}=$ dark red. Ground color of each fruit was rated on a scale of 1 to 4 , where $1=$ dark green and $4=$ yellow. Flesh firmness was measured on the green and red sides of each fruit with an Effigi firmness tester fitted with a 7.9-mm plunger (Model FT 327; McCormick Fruit Tech, Yakima, Wash.). SSC was determined for juice expressed from the red and green sides of each fruit with an Atago hand-held refractometer (Model N, McCormick Fruit Tech).

An analysis of variance (ANOVA), using the ANOVA procedure of the Statistical Analysis System (SAS) (Barr et al., 1985), was performed for each response variable to test equality of PPFD levels, shade periods, and girdling treatment. Results from ANOVA indicated a significant $(\boldsymbol{P} \leq 0.001)$ PPFD level by shade period interaction for all measures of fruit quality, and two- and three-way interactions for most of the other response variables (Table 1). Therefore, regression was performed for each shade period. Since shaded fruit often had greener ground color than desired, and ground color was associated with fruit maturity (Delwiche and Baumgardener, 1985), fruit quality response variables were analyzed with multiple regression using linear and quadratic components of ground color index as co- variates (noncontrolled variable) and the linear and quadratic components of percent IPPFD and the interaction term of percent IPPFD $\times$ ground color as regressor variables. Multiple regression was performed using the maximum $-\boldsymbol{R}^{2}$ improvement option of the stepwise procedure of SAS. The maximum $-\boldsymbol{R}^{2}$ improvement technique identifies the best one-variable model, the best two-variable model, etc. The model with the largest $\boldsymbol{R}^{2}$, and containing only independent variables that contributed significantly $(\boldsymbol{P} \leq 0.05)$ to the model, is presented in the tables. To test equality of girdling treatments within a shade period, data for the girdling treatments within each shade period were pooled and girdling was included as a dummy variable in the multiple regression model. When girdling contributed significantly to the model, regression was performed for each girdling treatment per shade period.

\section{Results . . .}

Fruit characters in this study were influenced by time of shading during the final fruit swell, the degree of shading, and girdling (Table 1). Shading 44 to $20 \mathrm{DBH}$ generally did not influence yield or fruit quality, whereas shading 44 to $0 \mathrm{DBH}$ had the greatest influence on response variables. The influence of shade was usually greater on girdled than nongirdled branches.

Preshade crop densities were similar for all treatment combinations and ranged from 5.3 to 6.9 fruit $/ \mathrm{cm}^{2}$ BCSA (Table 1). Shading branches 44 to $20 \mathrm{DBH}$ did not significantly influence the number of harvested fruit per branch, harvested yield per branch, fruit weight, harvested yield efficiency, preharvest fruit drop, or days from bloom to $50 \%$ harvest (Table 2). Number of harvested fruit per branch was influenced by the threeway interaction of percent IPPFD $\times$ shade period $\times$ girdling $(\boldsymbol{P}=0.07)$ (Table 1) and harvested yield per branch was influenced by the interaction of shade period $x$ girdling $(\boldsymbol{P}=0.06)$, so data were analyzed for each girdling treatment per shade period. When branches were shaded 20 to 0 or 44 to $0 \mathrm{DBH}$, number of fruit harvested per branch and harvested yield per branch were positively related to percent IPPFD, but the response to shading was greatest for girdled branches shaded 44 to $0 \mathrm{DBH}$ (Table 2). Fruit weight was influenced by the interaction of all three independent variables in this study (Table 1). Fruit weight on nongirdled branches was not related to percent IPPFD (Table 2). For nonshaded branches or branches shaded 44 to $20 \mathrm{DBH}$, fruit weight was greater on girdled than nongirdled branches (Table 2). For girdled branches shaded 20 to 0 and 44 to $0 \mathrm{DBH}$, fruit weight increased nonlinearly with increasing percent IPPFD.

Number of fruit harvested per branch and fruit weight are the two factors contributing to harvested yield per branch. Number of harvested fruit per branch and the associated harvested yield

Table 1. ANOVA tables for 'Biscoe' peach response variables including sources of variation and $P$ values.

\begin{tabular}{|c|c|c|c|c|c|c|c|c|c|c|c|}
\hline Sources & $\begin{array}{c}\text { Preshade } \\
\text { crop } \\
\text { density }\end{array}$ & $\begin{array}{l}\text { Harvested } \\
\text { fruit/branch }\end{array}$ & $\begin{array}{c}\text { Harvested } \\
\text { yield }\end{array}$ & $\begin{array}{l}\text { Fruit } \\
\text { wt }\end{array}$ & $\begin{array}{c}\text { Preharvest } \\
\text { drop }\end{array}$ & $\mathrm{H}_{50}$ & $\begin{array}{l}\text { Fruit } \\
\text { redness }\end{array}$ & $\begin{array}{l}\text { Red } \\
\text { intensity }\end{array}$ & $\begin{array}{l}\text { Ground } \\
\text { color } \\
\text { index }\end{array}$ & $\begin{array}{l}\text { Flesh } \\
\text { firmness }\end{array}$ & SSC \\
\hline & \multicolumn{11}{|c|}{ Prob $<F$} \\
\hline Shade period (S) & 0.335 & 0.750 & 0.560 & 0.001 & 0.113 & 0.001 & 0.001 & 0.001 & 0.001 & 0.001 & 0.001 \\
\hline Percent IPPFD (P) & 0.681 & 0.017 & 0.006 & 0.001 & 0.001 & 0.001 & 0.001 & 0.001 & 0.001 & 0.067 & 0.001 \\
\hline$S \times P$ & 0.536 & 0.630 & 0.598 & 0.001 & 0.031 & 0.001 & 0.001 & 0.001 & 0.001 & 0.001 & 0.001 \\
\hline Girdling (G) & 0.502 & 0.148 & 0.462 & 0.003 & 0.333 & 0.509 & 0.007 & 0.507 & 0.151 & 0.002 & 0.638 \\
\hline$S \times G$ & 0.464 & 0.129 & 0.057 & 0.001 & 0.047 & 0.894 & 0.043 & 0.180 & 0.117 & 0.011 & 0.001 \\
\hline$P \times G$ & 0.331 & 0.983 & 0.558 & 0.001 & 0.039 & 0.857 & 0.588 & 0.360 & 0.028 & 0.109 & 0.007 \\
\hline$S \times P \times G$ & 0.543 & 0.073 & 0.116 & 0.001 & 0.124 & 0.999 & 0.001 & 0.376 & 0.099 & 0.306 & 0.821 \\
\hline
\end{tabular}


Table 2. Yield, fruit weight, yield efficiency, preharvest fruit drop, and harvest date of 'Biscoe' peach trees as influenced by branch girdling and percent IPPFD during three periods during Stage III of fruit development, expressed as DBH.

\begin{tabular}{|c|c|c|c|c|c|c|c|}
\hline \multirow{2}{*}{$\begin{array}{l}\text { Shade } \\
\text { period } \\
\text { (DBH) }\end{array}$} & \multirow[b]{2}{*}{ Girdled } & \multicolumn{4}{|c|}{ Percent IPPFD } & \multirow[b]{2}{*}{ Regression model ${ }^{z}$} & \multirow{2}{*}{$\begin{array}{c}\text { Model } \\
R^{2}\end{array}$} \\
\hline & & 100 & 45 & 23 & 9 & & \\
\hline \multicolumn{8}{|c|}{ Harvested fruit (no./branch) } \\
\hline \multirow[t]{2}{*}{44 to 20} & No & 97 & 62 & 99 & 62 & NS & --- \\
\hline & Yes & 86 & 73 & 81 & 69 & NS & --- \\
\hline \multirow[t]{2}{*}{20 to 0} & No & 89 & 94 & 66 & 49 & $\mathrm{Y}=33.6+1.65 \%$ IPPFD $-0.01(\% \text { IPPFD })^{2}$ & 0.40 \\
\hline & Yes & 90 & 87 & 57 & 32 & $\mathrm{Y}=14.3+2.0 \%$ IPPFD $-0.01(\% \text { IPPFD })^{2}$ & 0.63 \\
\hline \multirow{2}{*}{44 to 0 . } & No & 111 & 111 & 39 & 31 & $\mathrm{Y}=27.1+0.92 \% \mathrm{IPPFD}$ & 0.58 \\
\hline & Yes & 98 & 76 & 37 & 17 & $\mathrm{Y}=15.2+0.89 \% \mathrm{IPPFD}$ & 0.56 \\
\hline \multicolumn{8}{|c|}{ Harvested yield ( $\mathrm{kg} /$ branch) } \\
\hline \multirow{2}{*}{44 to 20} & No & 14.3 & 9.1 & 14.3 & 8.6 & NS & $\cdots$ \\
\hline & Yes & 14.7 & 10.9 & 12.9 & 10.1 & NS &.-- \\
\hline \multirow[t]{2}{*}{20 to 0} & No & 13.4 & 13.3 & 9.1 & 7.2 & $Y=7.6+0.07 \%$ IPPFD & 0.36 \\
\hline & Yes & 15.8 & 12.8 & 7.2 & 4.2 & $Y=4.1+0.13 \%$ IPPFD & 0.66 \\
\hline \multirow[t]{2}{*}{44 to 0} & No & 16.9 & 13.5 & 5.0 & 4.2 & $Y=2.7+0.16 \%$ IPPFD & 0.70 \\
\hline & Yes & 16.4 & 11.2 & 4.9 & 1.7 & $\mathrm{Y}=0.9+0.16 \%$ IPPFD & 0.66 \\
\hline \multicolumn{8}{|c|}{ Fruit wt (g/fruit) } \\
\hline \multirow[t]{2}{*}{44 to 20} & No & 146 & 149 & 143 & 145 & NS & -- \\
\hline & Yes & 170 & 151 & 158 & 150 & NS & --- \\
\hline \multirow[t]{2}{*}{20 to 0} & No & 151 & 141 & 139 & 162 & NS & --- \\
\hline & Yes & 175 & 146 & 126 & 133 & $Y=129.5+0.005(\% \text { IPPFD })^{2}$ & 0.61 \\
\hline \multirow[t]{2}{*}{44 to 0} & No & 161 & 132 & 135 & 144 & NS & \\
\hline & Yes & 166 & 148 & 140 & 102 & $\mathrm{Y}=90.0+1.8 \%$ IPPFD $-0.01(\% \text { IPPFD })^{2}$ & 0.67 \\
\hline \multicolumn{8}{|c|}{ Harvest yield efficiency $\left(\mathrm{kg} / \mathrm{cm}^{2}\right)$} \\
\hline \multirow[t]{2}{*}{44 to 20} & No & 0.93 & 0.73 & 0.89 & 0.67 & NS & --- \\
\hline & Yes & 1.16 & Q.88 & 0.88 & 0.72 & NS & --- \\
\hline \multirow[t]{2}{*}{20 to 0} & No & 0.94 & 1.00 & 0.86 & 0.52 & $\mathrm{Y}=0.36+0.02 \%$ IPPFD $-0.00016(\% \text { IPPFD })^{2}$ & 0.53 \\
\hline & Yes & 0.91 & 0.97 & 0.71 & 0.30 & $\mathrm{Y}=0.05+0.03 \%$ IPPFD $-0.0002(\% \text { IPPFD })^{2}$ & 0.68 \\
\hline \multirow[t]{2}{*}{44 to 0} & No & 1.01 & 1.07 & 0.33 & 0.30 & $\mathrm{Y}=0.25+0.009 \%$ IPPFD & 0.68 \\
\hline & Yes & 1.07 & 0.96 & 0.38 & 0.12 & $\mathrm{Y}=-0.17+0.03 \%$ IPPFD $-0.0002(\% \text { IPPFD })^{2}$ & 0.73 \\
\hline \multicolumn{8}{|c|}{ Preharvest fruit drop (\%) } \\
\hline \multirow[t]{2}{*}{44 to 20} & No & 0 & 2 & 1 & 18 & NS & --- \\
\hline & Yes & 1 & 8 & 7 & 14 & NS & $\cdots$ \\
\hline 20 to $0^{y}$ & --- & 2 & 1 & 14 & 50 & $Y=76.3-2.7 \%$ IPPFD $+0.02(\% \text { IPPFD })^{2}$ & 0.68 \\
\hline \multirow[t]{2}{*}{44 to 0} & No & 2 & 0 & 55 & 62 & $Y=94.4-2.8 \%$ IPPFD $+0.017(\% \text { IPPFD })^{2}$ & 0.70 \\
\hline & Yes & 2 & 0 & 54 & 80 & $Y=106.2-2.65 \%$ IPPFD $+0.015(\% \text { IPPFD })^{2}$ & 0.69 \\
\hline \multicolumn{8}{|c|}{ Days from bloom to $50 \%$ harvest } \\
\hline 44 to $20^{y}$ & -- & 141 & 141 & 144 & 142 & NS & $\cdots$ \\
\hline 20 to 0 & $\ldots$ & 140 & 143 & 144 & 147 & $\mathrm{Y}=147.0-0.07 \%$ IPPFD & 0.62 \\
\hline 44 to 0 & --- & 140 & 145 & 152 & 153 & $\mathrm{Y}=153.9-0.13 \%$ IPPFD & 0.67 \\
\hline
\end{tabular}

zStepwise regression was performed using the linear and quadratic components of percent IPPFD as the regressor variables. All intercepts, regression coefficients, and coefficients of determination presented in the table differ from $0(P<0.05), \mathrm{n}=3$.

yData were pooled across girdling treatments because the interaction of girdling $\times$ percent IPPFD was not significant $(P<0.05)$, $\mathrm{n}=6$.

per branch were reduced by shading 20 to 0 and 44 to $0 \mathrm{DBH}$, because many fruit on shaded branches abscised before developing the desired ground color and were not harvested (Table $2)$. Since preharvest fruit drop was negatively related to percent IPPFD when branches were shaded 20 to 0 and 44 to $0 \mathrm{DBH}$, and shading nongirdled branches did not influence fruit weight, preharvest fruit drop was the primary cause of reductions in harvested fruit per branch, harvested yield per branch, and harvested yield efficiency of branches shaded 20 to 0 and 44 to 0 DBH. Days from bloom to $50 \%$ harvest was not influenced by girdling, but declined linearly with increasing percent IPPFD 20 to 0 and 44 to $0 \mathrm{DBH}$ (Table 2). Shading to $<23 \%$ IPPFD for 44 to $0 \mathrm{DBH}$ greatly increased days from bloom to harvest.

Red coverage and red intensity were significantly $(\boldsymbol{P}<0.05)$ related to percent IPPFD and ground color index for most shade period $\times$ girdling combinations, but the relationships were poor $\left(\mathrm{R}^{2}<0.35\right)$ for branches shaded 44 to 20 and 20 to $0 \mathrm{DBH}$
(Table 3). However, red coverage and red intensity were more strongly related to percent IPPFD and ground color index $\left(\mathrm{R}^{2}>0.50\right) 44$ to $0 \mathrm{DBH}$. Coverage and intensity of redness were greatest for fruit on branches shaded 44 to $20 \mathrm{DBH}$. When branches were shaded 44 to $20 \mathrm{DBH}$, red coverage decreased nonlinearly with increasing percent IPPFD and increased linearly with increasing ground color index, whereas red intensity was not related to percent IPPFD. Red coverage of fruit on branches shaded 20 to $0 \mathrm{DBH}$ was similar for all levels of percent IPPFD Red intensity was influenced by the interaction of percent IPPFD $\times$ ground color index, implying that the relationship between red intensity and ground color varied with differing percent IPPFD and the relationship between intensity and percent IPPFD varied with ground color.

Ground color index of fruit on branches shaded 44 to 20 or 20 to $0 \mathrm{DBH}$ was poorly related to percent IPPFD $\left(\mathrm{R}^{2}=0.07\right)$, but when branches were shaded 44 to $0 \mathrm{DBH}$ ground color index 
Table 3. 'Biscoe' peach fruit color, firmness, and SSC as affected by branch girdling, ground color index (GC), and percent IPPFD during three periods during Stage III of fruit development, expressed as DBH.

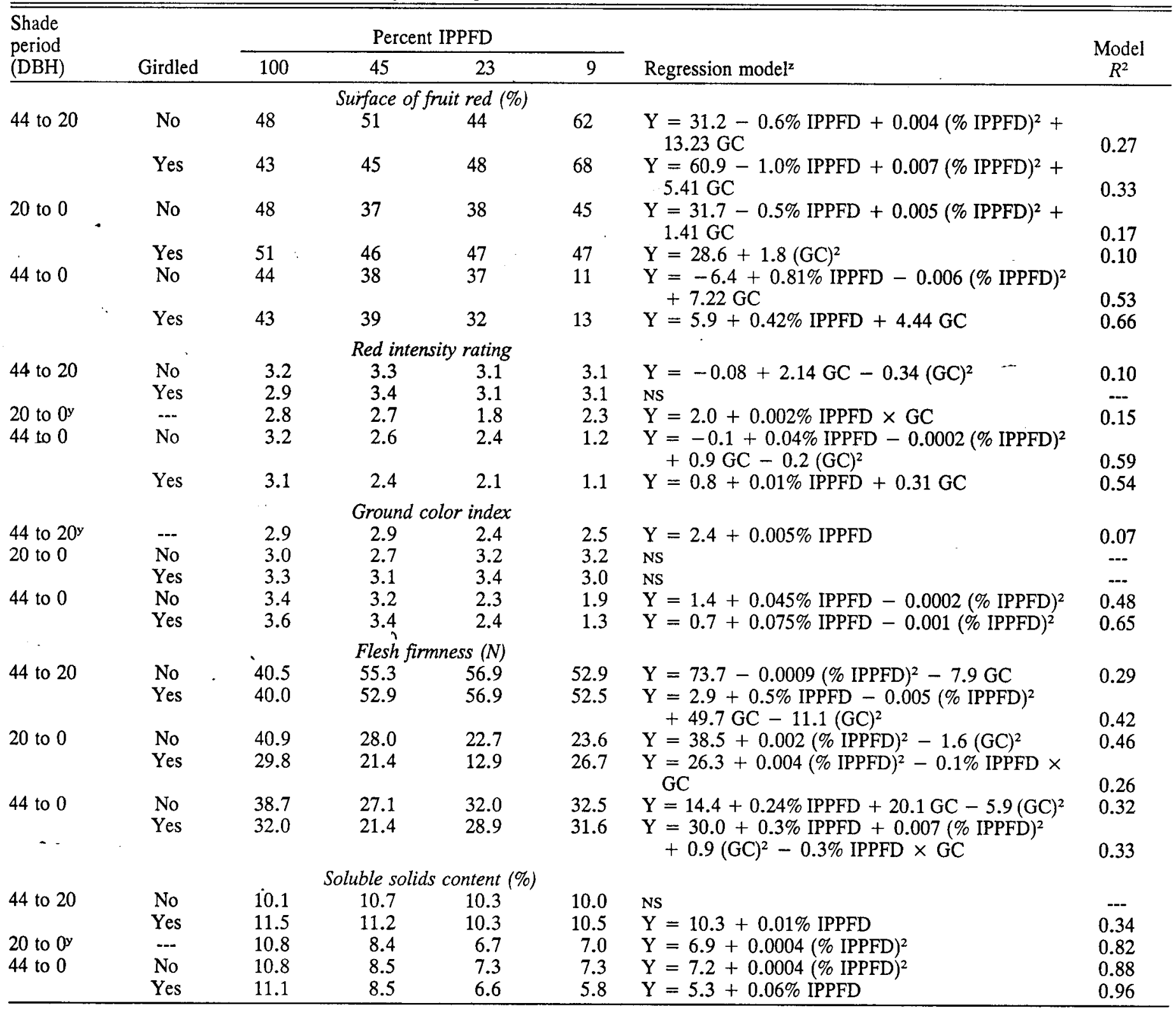

${ }^{2}$ Stepwise regression was performed using the linear and quadratic components of percent IPPFD as the regressor variables and the linear and quadratic components of ground color index as covariates. NS indicates that none of the independent variables significantly contributed to the model. All intercepts, regression coefficients, and coefficients of determination presented in the table differ from $0(P<0.05)$, $\mathrm{n}=60$.

'Data were pooled across girdling treatments because the interaction of girdling $\times$ percent IPPFD was not significant $(P<0.05), \mathrm{n}=120$.

increased nonlinearly with increasing percent IPPFD $\left(\mathrm{R}^{2} \geq 0.48\right)$ (Table 3). Fruit from branches exposed to $100 \%$ IPPFD for 44 to $0 \mathrm{DBH}$ had the highest ground color index and were the most yellow because harvest of these fruit was delayed while waiting for fruit on heavily shaded branches to develop appropriate ground color. Fruit on girdled branches shaded to $\geq 23 \%$ IPPFD 44 to $0 \mathrm{DBH}$ were more yellow than fruit from nongirdled branches, whereas the opposite was true for fruit on branches shaded to 9\% IPPFD.

Regardless of shade period, flesh firmness was significantly related to percent IPPFD and ground color index, but the regression models varied for the different shade periods (Table 3 ). When branches were shaded 44 to $20 \mathrm{DBH}$, flesh firmness decreased with increasing percent IPPFD, but when branches were shaded 20 to 0 or 44 to 0 DBH flesh firmness increased nonlinearly with increasing percent IPPFD. For branches shaded 20 to 0 and 44 to $0 \mathrm{DBH}$, the firmest fruit developed on branches exposed to $100 \%$ IPPFD and the softest fruit developed on branches exposed to $23 \%$ or $45 \%$ IPPFD. Compared with nongirdled branches, fruit on girdled branches shaded to $\leq 23 \%$ IPPFD for 20 to 0 or 44 to $0 \mathrm{DBH}$ were less firm.

Fruit SSC was generally highest on nonshaded girdled branches and lowest on girdled branches exposed to low percent IPPFD 44 to 0 DBF (Table 3). When branches were shaded 44 to 20 $\mathrm{DBH}$, fruit SSC increased linearly with increasing percent IPPFD for girdled but not nongirdled branches; and regardless of shade level, fruit SSC was greatest on girdled branches (Table 3). Regardless of girdling treatment, when branches were shaded 
20 to $0 \mathrm{DBH}$, fruit SSC increased nonlinearly with percent IPPFD. When branches were shaded 44 to $0 \mathrm{DBH}$, fruit SSC increased quadratically and linearly with increasing percent IPPFD for nongirdled and girdled branches, respectively.

\section{Discussion}

The fresh and dry weight increase of peach fruit exhibits a double-sigmoid pattern with a lag phase in dry weight increase in the middle of the season (Chalmers and van den Ende, 1975). During Stage I, cell division and some cell enlargement contribute to rapid fruit enlargement for $\approx 50$ days after bloom ,(Addoms et al., 1930). The length of Stage II varies with cultivar and is characterized by a low rate of fruit enlargement as the endocarp dry weight increases. During the final fruit swell (Stage III), which commences $\approx 6$ weeks before harvest (Blake et al., 1931; Walsh et al., 1989), fruit enlarge rapidly due to cell enlargement, flesh firmness declines as cell walls become thin, ground color changes from green to yellow as chlorophylls decline and carotinoids are synthesized, SSC increases, and fruit abscission occurs (Addoms et al., 1930; Chalmers and van den Ende, 1975). Theoretically, any factor that reduces photosynthesis should have the greatest influence on peach fruit during Stage III, when fruit are the major sink for photosynthate (Chalmers et al., 1975). Since shading 44 to $20 \mathrm{DBH}$ in this study had little influence on peach fruit weight and quality, PPFD is most important during the second half of Stage III of fruit development.

Photosynthate for fruit growth and development can come from leaves acropetal to the fruit, from leaves adjacent to the fruit, and from reserves and leaves basipetal to the fruit. The girdling applied in this study isolated shaded branches from the nonshaded portions of the tree to determine the importance of leaves adjacent and acropetal to the fruit. Nongirdled branches simulated shaded regions of a tree and fruit on these branches could be supplied with photosynthate from other parts of the tree. Since girdling interacted with shade period and/or percent IPPFD for most response variables in this study, translocated photosynthate is important for the development of peaches in shaded parts of a tree. Fruit weight was the response variable most strongly influenced by the interaction of all three variables. Fruit weight was greatest on nonshaded girdled branches and least on girdled branches shaded to 9\% IPPFD 44 to $0 \mathrm{DBH}$. The enhanced fruit weight on nonshaded girdled branches was probably due to the prevention of photosynthate translocation out of girdled branches to sinks beyond the girdle. Similar results were reported for peaches girdled at the end of Stage II of fruit growth (Chalmers et al., 1975; Powell and Howell, 1981) and sweet cherry girdled during Stage II or III of fruit growth (Roper et al., 1987). These data indicate that, in the absence of translocated photosynthate, peach fruit developing in heavy shade during the second half of the final fruit swell will not obtain maximum size. However, since fruit weight on nongirdled branches was not related to percent IPPFD, and IPPFD throughout open-center peach trees in the mid-Atlantic area usually is $>10 \%$ (Marini and Marini, 1983), the size of fruit developing in shaded locations of peach canopies is not limited by PPFD. These results are supported by data from other studies where weight of fruits growing at various canopy locations was poorly related to percent IPPFD for peach $\left(\mathrm{R}^{2}=0.03\right.$ ) (unpublished data), apple $\left(R^{2}=0.10\right)$ (Marini et al., 1986), and sweet cherry (Patten and Proebsting, 1986). However, other reports indicate a positive relationship between fruit size and PPFD for prunes (Southwick et al., 1990) and apples (Barritt et al., 1987). There may be at least two reasons why our data disagree with some previous reports for other tree fruits. PPFD at interior canopy positions may be greater in the eastern United States than in the west because PPFD penetration into apple canopies was greatest on partly cloudy days (Lakso and Musselman, 1976). PPFD at the interior of prune trees on a cloudless day in California averaged $\approx 30 \mu \mathrm{mol} \cdot \mathrm{s}^{-1} \cdot \mathrm{m}^{-2}$ (Southwick et al., 1990), whereas the lowest PPFD measured in peach trees on cloudy days in New Jersey was $\approx 45 \mu \mathrm{mol} \cdot \mathrm{s}^{-1} \cdot \mathrm{m}^{-2}$ (Marini and Marini, 1983). Therefore, PPFD at interior canopy positions maybe most limiting for fruit development in regions with little diffuse light. Secondly, the reason our relationships between fruit characters and percent IPPFD are not as strong as in previous reports may be due to differences in statistical analyses. Most researchers used means of a sample of at least five fruit from a canopy location for regression analysis (Barritt et al., 1987; Robinson et al., 1983; Southwick et al., 1990). In contrast, we included each fruit as an observation, which typically increases the variation, lowers the coefficient of determination, and lowers the $P$ value.

Days from bloom to $50 \%$ harvest was not influenced by girdling, but was greatly increased by shading to <23\% IPPFD for 44 to $0 \mathrm{DBH}$. Shading sweet cherry limbs to $10 \%$ to $15 \%$ IPPFD from petal fall to harvest delayed minimum harvest maturity color 12 days, and compared with nonshaded limbs, shading from petal fall to pit hardening or pit hardening to harvest delayed maturity 5 days (Patten and Proebsting, 1986).

In our study, red coverage varied depending on shade period and percent IPPFD. Coverage was negatively related to percent IPPFD when branches were shaded 44 to $20 \mathrm{DBH}$, was poorly related to percent IPPFD 20 to $0 \mathrm{DBH}$, and was positively related to percent IPPFD 44 to $0 \mathrm{DBH}$. Previous reports parallel our data. Proctor and Lougheed (1976) reported that 'McIntosh' apples formed more anthocyanin if covered with foil bags and then exposed 20 to $30 \mathrm{DBH}$ than if continually exposed. 'Redhaven' fruit covered with aluminum foil for 15 days and then exposed to full sun 3 days before harvest developed at least $63 \%$ of the red coverage of nonshaded fruit (Erez and Flore, 1986). Commercial peach producers may be able to take advantage of this rapid color development following shade removal by summer pruning to improve light penetration 14 to $21 \mathrm{DBH}$. Red coverage was increased $11 \%$ by summer topping 'Sunqueen' peach trees $\approx 35 \mathrm{DBH}$ (Marini, 1985). Compared to nonshaded fruit, fruit exposed to $23 \%$ IPPFD 44 to $0 \mathrm{DBH}$ were considerably greener but still developed $84 \%$ as much red coverage. Our data indicate that only the fruit at canopy positions receiving $<23 \%$ IPPFD would develop poor red coverage.

As peaches approach maturity, the ground color changes from green to yellow as chlorophyll concentrations decline and carotenoids increase (Addoms et al., 1930). Chalmers and van den Ende (1975) reported that chlorophyll concentration increased during FW I, decreased rapidly during the first half of FW II, then declined less rapidly through the first half of FW III before declining rapidly during the second half of FW III. Our data indicate that ground color change during the second half of Stage III is not influenced by shading and that only shading to $\leq 23 \%$ IPPFD for most of Stage III prevents ground color yellowing.

The relationship between flesh firmness and percent IPPFD varied with shade period. When branches were shaded during the first half of Stage III, flesh firmness was negatively related to percent IPPFD. When branches were shaded during the second half of Stage III or all of Stage III, flesh firmness was 
positively related to percent IPPFD. Blake et al. (1931) found that peach flesh firmness was negatively related to fruit growth rate throughout the season. Firmness increased until the middle of Stage II as cell walls thickened (Addoms et al., 1930). As fruits started to enlarge during the second half of Stage II, cell wall thickness and flesh firmness started to decline. Flesh firmness declined rapidly during Stage III. Since flesh firmness.was related to cell wall thickness and cell walls are composed of photosynthate, it is possible that shading girdled branches may reduce flesh firmness. The fact that flesh firmness was affected by the interaction of percent IPPFD $\times$ girdling (Table 1$)$ may support the above hypothesis.

It is difficult to determine the influence of PPFD on flesh firmness in this study because flesh firmness generally declines as ground color becomes yellow, and fruit from different treatments were not harvested with similar ground color. Therefore, it is possible that firmness was related to maturity, rather than percent IPPFD. Assessing the influence of percent IPPFD on flesh firmness is further complicated by the fact that the relationship between flesh firmness and ground color index varied for the different shade periods. Flesh firmness and ground color generally are used as indices of maturity for fresh peaches (Rood, 1957), and the two indices are usually linearly and negatively related (Delwiche and Baumgardener, 1983). In our study, when fruit were shaded 44 to $20 \mathrm{DBH}$, flesh firmness declined linearly with increasing ground color index $\left(R^{2}=0.69\right)$, but firmness was not significantly related to ground color $\left(R^{2} \leq 0\right.$. 14) for the other shade periods. Blake et al. (1931) also found that the firmness of peaches with similar ground color from different orchards sometimes differed markedly. Since fruit shaded to $\leq 23 \%$ IPPFD 44 to $0 \mathrm{DBH}$ had greener ground color but were no firmer than nonshaded fruit, fruit from shaded branches may have been harvested at similar maturities despite differences in ground color. We are unaware of similar reports in the literature and additional work is needed to determine if the relationship between ground color and flesh firmness varies for different locations in peach tree canopies.

Our data indicate that the SSC of fruit harvested from various canopy locations is not related to PPFD during the first half of Stage III. Since fruit on nongirdled branches shaded 20 to 0 or 44 to 0 DBH had similar SSC, high PPFD during the second half of Stage III is most important for maximum SSC. This conclusion is supported by the work of Chalmers and van den Ende (1975), where soluble sugars increased exponentially during FW III. Positive relationships between fruit SSC and percent IPPFD have also been reported for sweet cherry (Patten and Proebsting, 1986), prunes (Southwick et al., 1990), and apple (Barritt et al., 1987). The interaction between branch girdling and percent IPPFD in our study indicates that fruit SSC partially depends on photosynthate translocation from nonshaded parts of the tree. This concept is supported by other work that found a poor relationship between peach SSC and percent IPPFD measured next to fruit at various canopy locations (Grappadelli, 1985; R. P.M., unpublished data).

Results from this study indicate that PPFD is important for certain peach fruit quality characters, but fruit development during the final swell varies with time and level of PPFD. Since shading nongirdled branches 44 to $20 \mathrm{DBH}$ had little influence on fruit weight and quality, peach fruit development in shaded locations of trees is not limited by PPFD during the first half of the final fruit swell. However, low PPFD during the final 20 DBH may adversely affect fruit quality. Since fruit weight on nongirdled branches was not strongly related to percent IPPFD, reported levels of $\geq 10 \%$ IPPFD throughout the canopies of open center trees (Marini and Marini, 1983) and various hedgerow systems (Kappel et al., 1983; Rom et al., 1984) appear adequate for development of large peaches. Shading to 45\% IPPFD had little effect on most aspects of fruit quality, but IPPFD levels $\leq 23 \%$ for 6 weeks before harvest may delay ground color development and reduce fruit red coverage and SSC of peach. Low PPFD during the final 3 weeks before harvest only affected days from bloom to harvest and fruit SSC. Girdling results indicate that peach fruit weight and SSC at least partially depend on photosynthate from nonshaded parts of the tree, whereas fruit red coverage, days to harvest maturity, and associated ground color depend on PPFD in the immediate vicinity of the fruit.

The influence of PPFD on the relationship between ground color and flesh firmness deserves further study because there may be commercial implications. Fruit with similar ground color, but harvested from various canopy positions, may not have similar flesh firmness or storage life. Results from this study can be used to modify commercial peach production practices to improve fruit quality. Minimizing shade several weeks before harvest by summer pruning or repositioning branches may negate most effects of shade during the first half of the final fruit swell.

\section{Literature Cited}

Addoms, R. M., G.T. Nightingale, and M.A. Blake. 1930. Development and ripening of peaches as correlated with physical characteristics, chemical composition, and histological structure of the fruit flesh: II. Histology and microchemistry. N.J. Expt. Sta. Bul. 507.

Barr, A.J., J.H. Goodnight, J.P. Sail, and J.T. Helwig. 1985. SAS user's guide: Statistics, version 5 (ed.) SAS Institute, Inc., Cary, N.C.

Barritt, G.H., C.R. Rem, K.R. Guelich, S.R. Drake, and M.A. Dilley. 1987. Canopy position and light effects on spur, leaf, and fruit characteristics of 'Delicious' apple. HortScience 22:402-405.

Bittenbender, H.C. and G.S. Howell, Jr. 1974. Adaptation of the Spearman-Karber method for estimating the $T_{50}$ of cold stressed flower buds. J. Amer. Soc. Hort. Sci. 99:187-190.

Blake, M. A., O.W. Davidson, R.M. Addoms, and G.T. Nightingale. 1931. Development and ripening of peaches as correlated with physical characteristics, chemical composition, and histological structure of the fruit flesh: I. Physical measurements of growth and flesh texture in relation to the market and edible qualities of the fruit. N.J. Expt. Sta. Bul. 525.

Chalmers, D.J. and B. van den Ende. 1975. A reappraisal of the growth and development of peach fruit. Austral. J. Plant Physiol. 2:623634.

Chalmers, D. J., R.L. Canterford, P.H. Jerie, T.R. Jones, and T.D. Ugalde. 1975. Photosynthesis in relation to growth and distribution of fruit in peach trees. Austral. J. Plant Physiol. 2:635-645.

Delwiche, M.J. and R.A. Baumgardener. 1983. Ground color measurements of peach. J. Amer. Soc. Hort. Sci. 108:1012-1016.

Delwiche, M.J. and R.A. Baumgardener. 1985. Ground color as a peach maturity index. J. Amer. Soc. Hort. Sci. 110:53-57.

Erez, A. and J.A. Flore. 1986. The quantitative effect of solar radiation on 'Redhaven' peach fruit skin color. HortScience 21:1424-1426.

Grappadelli, L.C. 1985. Effects of flower bud position and canopy light environment on time of flowering and fruit quality in peach [Prunu.spersica (L.) Batsch]. MS Thesis, Clemson Univ., Clemson, S.C.

Jackson, J.E. 1980. Light interception and utilization by orchard systems. Hort. Rev. 2:208-267.

Kappel, F., J.A. Flore, and R.E.C. Layne. 1983. Characterization of the light microclimate in four peach hedgerow canopies. J. Amer. Soc. Hort. Sci. 108:102-105.

Lakso, A.N. and R.C. Musselman. 1976. Effects of cloudiness on interior diffuse light in apple trees. HortScience 101:642-644. 
Marini, R.P. 1985. Vegetative growth, yield, and fruit quality of peach as influenced by dormant pruning, summer pruning, and summer topping. J. Amer. Soc. Hort. Sci. 110:133-139.

Marini, R.P. and M.C. Marini. 1983. Seasonal changes in specific leaf weight, net photosynthesis, and chlorophyll content of peach leaves as affected by light penetration and canopy position. J. Amer. Soc. Hort. Sci. 108:609-613.

Marini, R.P. and R. Trout. 1984. Sampling procedures for mirrimizhg variation in peach fruit quality. J. Amer. Soc. Hort. Sci. 109:361-364.

Marini, R. P., D. Sowers, and M.C. Marini. 1986. Specific leaf weight as an indicator of apple fruit quality. HortScience 21:692. (Abstr.)

Morgan, D. C., C.J. Stanley, R. Volz, and I.J. Warrington. 1984. Summa pruning of 'Gala' apple: The relationships between pruning time, radiation penetration, and. fruit quality. J. Amer. Soc. Hort. Sci. 109:637-642.

Patten, K.D. and E.L. Proebsting. 1986. Effect of different artificial shading'limes and natural light intensities on the fruit quality of 'Bing' sweet cherry. J. Amer. Soc. Hort. Sci. 111:360-363.

Powell, A.A. and C. Howell. 1981. Using girdling, scoring and growth regulator to increase yields and fruit size of peaches. HortScience 16:440. (Abstr.)

Proctor, J.T.A. and E.C. Lougheed. 1976. The effect of covering apples during development. HortScience 11:108-109.
Robinson, T. L., E.J. Seeley, and B.H. Barritt. 1983. Effect of light environment and spur age on 'Delicious' apple fruit size and quality. J. Amer. Soc. Hort. Sci. 108:855-861.

Rem, C. R., D.C. Ferree, and G.A. Cahoon. 1984. The influence of three training systems within hedgerows on light distribution, cropping, and efficiency of 'Redhaven' and 'Redskin' peaches. The Ohio State Univ. Res. Circ. 283:49-53.

Rood, P. 1957. Development of objective maturity indices for California freestone peaches. Proc. Amer. Soc. Hort. Sci. 70:104-112.

Roper, T. R., W.H. Loescher, J. Keller, and C.R. Rem. 1987. Sources of photosynthate for fruit growth in 'Bing' sweet cherry. J. Amer. Soc. Hort. Sci. 112:808-812.

Seeley, E. J., W.C. Micke, and R. Kammereck. 1980. 'Delicious' apple fruit size and quality as influenced by radiant flux density in the immediate growing environment. J. Amer. Soc. Hort. Sci. 105:645-657.

Southwick, S. M., S.A. Weinbaum, T.T. Muraoka, W.R. Krueger, K.A. Shackel, and J.T. Yeager. 1990. Leaf attributes as indices of fruit quality in prune tree canopies. HortScience 25:751-754.

Walsh, C. S., F.J. Allnutt, A.N. Miller, and A.H. Thompson. 1989. Nitrogen level and time of mechanical summer shearing influence long-term performance of a high-density 'Redskin' peach orchard. J. Amer. Soc. Hort. Sci. 114:373-377. 